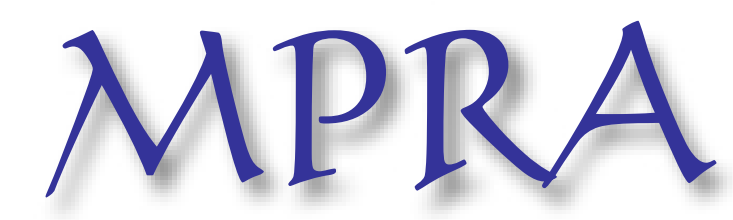

Munich Personal RePEc Archive

\title{
REVISITING COMMONS - ARE COMMON PROPERTY REGIMES IRRATIONAL?
}

Hasan, Lubna

Pakistan Institute of Development Economics

January 2002

Online at http://mpra.ub.uni-muenchen.de/8316/ MPRA Paper No. 8316, posted 12. August 2008 / 10:43 


\title{
REVISITING COMMONS - ARE COMMON PROPERTY REGIMES IRRATIONAL?
}

\author{
Lubna Hasan \\ Pakistan Institute of Development Economics \\ Islamabad
}

January, 2002

\begin{abstract}
This paper revisits the debate about communal management of natural resources and brings together various issues confronting it. Much of the criticism against common property regimes stems from an incorrect modeling of a common property situation, and misunderstandings about the terms and their wrong usage. Models of collective action (Hardin's tragedy of the Commons, Olson's Logic of Collective Action, and the Prisoner's Dilemma) that are used as critique against common property regimes are not based on an accurate depiction of reality, and many of their assumptions are untrue. The purpose is to drive home the point that common property regimes are not inherently inferior types of regimes, and causes of success, and of failures, of these regimes lie elsewhere. Secondly, both public [and also private] management of natural resources has not had universal success. It is time to think out of the usual 'either public or private' dichotomy. Combining elements of both public and communal management in a pragmatic way is necessary. It is time to give co-management a serious thought!
\end{abstract}

Key Words: Natural Resource Management, Property Institutions.

JEL Classification: Q20, P14.

\section{INTRODUCTION}

In recent years communal management of natural resources has resurfaced as an issue in natural resource and environmental economics. For decades, this form of management had been relegated to a secondary position on account of being inferior to public or private management, owing to "Tragedy of the Commons". However, 
disillusionment with the latter types, especially public regimes, had sparked a revival of interest in common property regimes (CPRs), and study of CPRs has become an established field in natural resource economics.

This research endeavor has been multifaceted. On one hand, it has focused on practical issues of compiling empirical evidence in favor of common property regimes and identifying conditions for their success, as well as challenges faced by them [Bromley (1992), Berkes (ed.) (1989), McCay and Acheson (1987)]. On the other, it seeks to tackle conceptual issues haunting this debate, which in its own sense is important because much of the criticism against common property regimes stems from (1) an incorrect modeling of a common property situation, and (2) misunderstandings about the terms and their wrong usage [Knudsen (1995), Ostrom (1999), (1990), Wade (1987)]. In terms of policy making, much ground has been covered for the 'inclusive' concept of development, where state and citizens work in unison. For the sake of common property regimes, it meant they could now be co-opted in the 'co-management' in solving particular resource management problems where state management had not proved to be effective. Yet, it seems governments in developing countries have not embraced the idea whole heartedly and the concept of including 'people' in resource management has remained elusive, marked more by rarity than by its preeminence. Phrases like 'anti-tree' attitudes, and antipathy [rather animosity] ${ }^{1}$ of people toward natural resources still dot the policy documents, and in many cases only lip service is paid to 'co-management', which is seen more as donor-driven policy agenda ${ }^{2}$.

This paper revisits the debate about communal management of natural resources and brings together various issues confronting it. It begins by contextualizing the current debate on common property regimes, followed by a discussion, and clarification of many misconceptions and misunderstanding that render this debate a bit vague. The next section critically evaluates the models of collective action- namely Hardin's tragedy of the Commons, Olson's Logic of Collective Action, and the Prisoner's Dilemma- used in arguments against CPR. Section five is devoted to policy implications i.e. the publicprivate dichotomy, and its fallouts. By this time we hope to have made a sufficient ground for common property regimes. The sixth section serves that purpose. And finally

\footnotetext{
${ }^{1}$ For example, reflecting on the relationship between the Forest Department and forest communities in the case of Pakistan, Dove (1994) notes that "the Forest Department has an attitude of mistrust towards local population and attributes overexploitation of tree products and deforestation of forested area to the 'anti-tree' attitudes of the rural people.

${ }^{2}$ Even a casual screening of the Government of Pakistan's Forestry Sector Master Plan (1992) reveals that government considers local people as the primary cause behind high deforestation rates in Pakistan and recommends strengthening government's control over forests. [Hasan (2001)].
} 
we have the concluding comment. The purpose is to drive home the point that common property regimes are not as irrational as hypothesized, and not necessarily bound to fail, as claimed. Secondly, public [and also private] management of natural resources has not had universal success. It is time to think out of the usual 'either public or private' dichotomy. Combining elements of both public and communal management in a pragmatic way is necessary. It is time to give co-management a serious thought!

\section{PROPERTY REGIMES AND NATURAL RESOURCE MANAGEMNT}

\section{What is common to the greatest number gets the least amount of care}

Aristotle

All human life involves the use of material resources ${ }^{3}$ and the question of control and allocation of these resources arise in every society. A primal concern of societies is to decide upon the basic principles of this allocation. The problem arises because resources are scarce, compared to demands made on them. "Each society faces the problem of determining which, among the many competing claims on the resources available for use in the society are to be satisfied, when, by whom, and under what conditions” [Waldron (1988): 39). ${ }^{4}$ Property system, which is a system of rules governing access to and control over resources, solves this problem of allocation [ibid]. Typically, Property rights are relations among individuals that arise from the existence of scarce goods and pertain to their use. They specify the behaviourial norms with respect to objects that all people must observe in their interaction with other people or bear the penalty cost of non-observance [Pejovich (1990)].

The debate about property has generally revolved around the meaning, the sequence of development but also about the 'superior' form of property [Ostrom (1999)]. ${ }^{5}$ Property institutions and their role in shaping resource use patterns have also been studied

\footnotetext{
${ }^{3}$ Resources are material things that can satisfy some human wants.

${ }^{4}$ The concept of scarcity is worth emphasizing. If resources were abundant we need not have to worry about their allocation and use. Their "scarcity is the presupposition of all sensible talk about property" [Waldron (1988: 31)].

${ }^{5}$ Despite the fact that property systems encompass a continuum of possibilities from pure private to pure public regimes, the contemporary focus, especially during the cold war era, had narrowed down the choice between either the system of private property (the capitalist model) or that of public property (the socialist model); and relative superiority of either type and related economic system [Reeve (1986), Waldron (1988), Pejovich (1990). See also Williamson (1985)].
} 
extensively. The manner in which people use environmental resources depends on the property rights governing those resources [Tietenberg (1994)]. It is argued that since human beings interact with their environment through institutions of property, and since much of the environmental deterioration is attributed to human activities, roots of environmental problems are to be traced to inadequate and ill-defined property institutions [Hanna and Munasinghe (1995)]. ${ }^{6}$

These property institutions are a part of over all institutions of a society [North (1990)]. Institutions are a set of rules that govern and constrain human interaction. ${ }^{7}$ The role of institutions in determining economic performance has been widely studied. ${ }^{8}$ Since institutions define the framework within which human interactions take place, and hence structure human behaviour, our environment, and more specifically, the resource use pattern is influenced by it.

Though, property regimes vary in nature across a continuum from pure public to pure private, three types of regimes are typically focused: public property, private property and common property ${ }^{9}$. They all differ in their ability to exclude non-right holders. Public Property Regimes are those where ownership (and control) over the resource belongs to the state. Although rights of use may be available for the public, the title does not rest with them. In a public property system the problem of allocation is solved by a social rule. The rule takes the collective interest of the society as the focal point, and use of resources is determined with respect to this interest [Waldron (1988)].

Private Property Regime is organized around the idea that each object belongs to some individual. Here individuals (and private entities) maintain ownership and control over the resources. A rule is laid down that in the case of each object the owner of that object is to determine how the object shall be used. His decision is to be upheld by the society as final (ibid). Private property gives its owner a legal right to exclude others.

Common Property Regime implies a group property where a well-defined set of user has access and control rights over the resource. In a system of common property, rules governing access to and control of resources are organized on the basis that each

\footnotetext{
${ }^{6}$ Hanna and Munasinghe write that most of the environmental problems can be seen as problems of “incomplete, inconsistent, or unenforced property rights regimes" [Hanna and Munasinghe (1995), p. 15].

${ }^{7}$ This definition of institutions is adopted from North (1990).

${ }^{8}$ This concept is explored by the NIE School of Thought. According to this school of thought institutions are important in determining the economic outcomes because they, together with other economic constraints, define the opportunity (or choice) set of individuals. [See Harris et al. (1995); North (1990, 1991); Ostrom (1990); Eggertsson (1990)].

${ }^{9}$ Literature on CPRs also makes reference to the fourth regime called "non- Property Regimes (open access). We will discuss this type below.
} 
resource is in principle available for the use of every member alike (Waldron 1988, p. 41). A common property regime shares some of its features with that of public property in that no individual stands in a specially privileged situation with regard to any resource ${ }^{10}$, and some with private property regime in the sense that the resource is held like a private property by the group to the exclusion of non-owners.

Much of the interest in property institutions and natural resource management is invoked by the Property Rights School ${ }^{11}$. They stress that property rights, which determine conditions of access to and control over scarce resources, have impact on the outcome of the natural resource sector. ${ }^{12} \mathrm{~A}$ well-defined structure of property rights induces efficiency in the use of resources. ${ }^{13}$

Posner (1973) argues that the function of property rights is to create a structure of incentives to use resources efficiently. ${ }^{14} \mathrm{~A}$ "well-defined" structure of property rights would have four important features, i.e., rights are universal, exclusive, transferable and enforceable. ${ }^{15}$ Exclusivity implies exclusive ownership and a right to exclude nonowners. It creates a link between one's right to choose how to use the asset and bearing the consequences of that choice. Since the owner of the asset is the only person who will receive benefits from that decision, he will have an incentive to put his asset to the highest value use. Transferability provides incentive to move resources from less productive to more productive opportunities [Pejovich (1990:29)]. Enforceability means security from involuntary seizure or encroachment by others, what Honore calls a right to security against the expropriation of the asset. ${ }^{16}$

Together these four conditions determine an efficient structure of property rights. In case of an inefficient structure of property rights, i.e. when rights are either not well defined and or not enforced, the private rate of return from an economic activity will differ from the social rate of return. This discrepancy implies that a third party will receive some of the benefits or will incur some of the costs. If this difference is large enough, such that the private costs exceed the private benefits, individuals will not be

\footnotetext{
${ }^{10}$ But it is different in the sense that the interest of the collective has no special status.

${ }^{11}$ See Dragun (1987), Quiggin (1988), and Nabli and Nugent (1989) for a review.

12 Though this school of thought implies that property rights have impact on the overall economic performance, but for the sake of this article their arguments are limited to natural resource sector.

${ }^{13}$ Demsetz (1967) is one of the pioneering works on this field. Other prominent supporters of this view include Pejovich (1990), Tietenberg (1994, 1992), Tisdell (1993). Posner argues that the function of property rights is to create a structure of incentives to use resource efficiently [c.f. Reeve (1986): 23].

${ }^{14}$ Cited from Reeve (1986), p. 23.

${ }^{15}$ The first three features are identified by Posner (1973) (cited from Reeve 1986) and the last feature is highlighted by Tietenberg (1992).
} 
willing to under take socially profitable activities. Economic activities will shrink as a result. "The transfer of property rights amongst individual owners through contracting in the market place requires that the right be exclusive. Not only must the rights be measurable; they must also be enforceable” [North (1981: 36)].

\title{
III. MISPERCEPTIONS, CONFUSIONS AND THE COMMONS - COMMON PROPERTY REGIMES IN CONTEMPORARY PERSPECTIVE
}

\author{
Men pay most attention to what is their own: they \\ care less for what is common...men are more prone \\ to neglect their duty when they think another is \\ attending to it. ${ }^{17}$
}

The Property Rights School asserts that a well-defined structure of property rights induces efficiency in the use of resources. According to the critics of CPRs, these regimes fail the efficiency criteria on many accounts. Firstly, since resources managed under CPRs are group property and nobody is in any privileged position to claim exclusive ownership, a resource unit has to be physically captured to lay claim on it. This leads to 'rent dissipation'. Secondly, since devising and enforcing rules requires collective action and group consensus, transaction $\operatorname{costs}^{18}$ associated with CPRs are high $^{19}$. Thirdly, since, in a group property there is a loose connection between personal effort and returns, the resource is bound to suffer from low yield [Ostrom (1999)].

Another point of criticism against CPRs is the 'economic rationality' argument. Accordingly, even if a stint rule in the use of a resource is agreed upon by the user group, collective action required for observing that rule is bound to fail since a rational individual will find it to his own benefit to ignore the rule and over-exploit the resource, with the perception that if he does not capture the benefits others will do so. We will take up this argument in the next section.

\footnotetext{
${ }^{16}$ Reeve (1986) discusses that interest in a resource is conceptually linked to the means available to protect it. A claim to a resource is taken to be good against and legally guaranteed against any rival claims.

${ }^{17}$ Aristotle in Politics, 1262. c.f. Waldron 1988, p. 6, emphasis added .

${ }^{18}$ Transaction costs include measurement costs and enforcement costs [North (1990)].

${ }^{19}$ See also Demsetz (1967) for this point.
} 
One other source of concern in the debate about common property management is the problem of misperceptions. Discussions about common property resource management are often afflicted with problems of misunderstanding and confusion among different terms, e.g. between a resource and regime, between common property and open access regimes.

We first deal with the problem associated with confusing a common pool resource with a common property regime. The discussion usually puts the entire burden of mismanagement of common pool resources on CPRs. It ignores the fact that common pool resources have certain characteristics (difficulty of exclusion, susbtractibility) that make them difficult to manage under any kind of regime. This point will be elaborated below, but first some definitions are in order here.

Resources are defined as something that offers benefits to human beings. An entity becomes a resource when people develop ability to command that benefit stream [Dani, Gibbs and Bromley (1987)]. Reeve (1986) describes resources as objects of want: something people wish for because it provides satisfaction, either direct or indirect, to them. Common pool resources as "natural or man made resources where exclusion is difficult and yield is subtractable. As such they share their first attribute with pure public goods and the second attribute with pure private good. The first attribute, difficulty of exclusion, results from factors such as cost of parcelling or fencing the resource and the cost of designing and enforcing property rights to exclude access to the resource. It is this attribute of common pool resource that makes them prone to free riding by others. The second attribute of subtractability means that resource unit that one person appropriates from the common-pool resource is not available to others” [Ostrom and Gardner (1993: 93)]. These two attributes collectively make common pool resources vulnerable to extinction. ${ }^{20}$

This vulnerability of common pool resources warrants the need to regulate the behaviour of its users. Rules have to be set for a sustainable level of exploitation of the resource; some kind of enforcement mechanism is needed as well. This function is provided by the resource regime. Typically, a resource regime refers to a structure of rights and duties characterising the relationship of individuals to one another with respect to that particular resource [Bromley and Cernea (1989:5)]. We have discussed the property regimes at some length above.

While common pool resources have certain characteristics peculiar to them (subtractability, difficulty of exclusion), they can be managed under various kinds of

\footnotetext{
${ }^{20}$ The notion of resource management stems from their scarcity, if they were in unlimited supply the need may not have arisen. This applies to all resources and not just common property resource.
} 
regimes. That is, they can be managed under public, private or common property regimes (or any mix of these regimes). For example, forestlands are managed by state institutions in Pakistan (and also elsewhere) [see Hasan (2001)]. Village commons have been privatized in India [Jodha (1994)]. Experience has shown that neither state nor private management of these resources has had universal success [see the two studies cited above]. In their haste, critics of CPRs wrongly associate problems related with the management of common pool resource to the common property regime.

Second misconception relates to confusing common property regimes with open access regimes. While $\mathrm{CPR}$ has well-defined user group and use rights, open access regimes confer no such property rights. A resource under this regime belongs to the party that captures it first ${ }^{21}$. If property management arrangements are not determined then it can be predicted that the resource will eventually face extinction [Bromley and Cernea (1989)]. Critics of CPRs wrongly characterize them with situations that are more aptly defined as one with open access (no property rights). The problem of open access regime can arise when a resource, which is nominally under a particular (public, private or common) regime, is left unmanaged, and is not peculiar to CPRs only.

\section{MODELS OF COLLECTIVE ACTION AND COMMON PROPERTY REGIMES}

Common Property Regime consists of a well-defined and recognized group of users, a well-defined resource that the group manages and uses, and a set of institutional arrangements regulating its use. The resources held under such an arrangement are used by individuals but are not individually owned. They are a group property. This means that rules, which are developed for the use of a particular resource, must have the consensus of the group and each individual must abide by the rule. Thus, management of resources under common property system requires collective action in the formulation of rules of restrained use and in its observance $\boldsymbol{e}^{22}$.

A certain degree of pessimism prevails among analysts regarding the viability of common property regimes. Much of this stems from their lack of faith in the ability of resource users to act collectively in the sense described above. Their scepticism is based on

${ }^{21}$ Bromley and Cernea (1989) define open access regime as one where "each potential user has complete autonomy to use the resource since on-one has the legal ability to keep any potential user out. The natural resource is subject to the rule of capture and belongs to no-one until it is in someone's physical possession” [Bromley and Cernea (1989): 21]. 
several theories of collective action. These are (1) the Prisoner's Dilemma, (2) the Hardin's Tragedy of the Commons, and (3) the Theory of Collective Action. Before dealing with them separately it will be benefiting to say what these theories imply. In essence, they all point to the problems associated with collective action and conclude that this may be an impossibility. If a group of user is required to act collectively, i.e., adopt a stint rule in the use of a resource, and this action is mutually beneficial to all of them, they will not do so unless an external agency imposes this rule on them. These theories contend that a "rational"23individual will find it to his own benefit to ignore the rule and over exploit the resource (free riding), fearing that if he does not do so others will capture the benefits. We now discuss the models separately, the objective will be to show that what these theories infer as compulsory outcome need not be the case for every situation requiring collective action- free riding remains a possibility but not an imperative. ${ }^{24}$

The Prisoner's Dilemma is visualized as a non-cooperative game in which communication among players is forbidden. Each player has complete information about the full structure of the game tree and the payoffs attached to outcomes. Each player has a dominant strategy, meaning that the player is always better off choosing that strategy.

\section{Box 1: The Prisoner's Dilemma Game}

The game involves two persons [ $\mathrm{A}$ and $\mathrm{B}$ ], who are being question in isolation about a crime they had committed together. There is no communication between them and each person chooses only once, i.e. they cannot change the outcome afterwards. Each person faces the following scenario. If both persons cooperate, i.e. they remain silent, they will be set free. If person A cooperates and B defects then A will face long prison and B will go free. If both confess [i.e. defect], each one will get medium prison. The most desirable outcome is that both remain silent (i.e. cooperate) and that is a superior outcome. The dilemma that each faces is that in case he cooperates and the other one defects, he will be suckered. For each one of them, staying silent while the other defects, gives the worst outcome (long prison). Confessing the crime ensures that this worst outcome will be averted. So the rational strategy for both of them is to confess, and this is their dominant strategy.

\footnotetext{
${ }^{22}$ Collective action is action by more than one person to achieve some common goal, or to satisfy some common interest; a goal or an interest that can not be achieved by a person acting alone (Wade 1987, p 97).

${ }^{23}$ Mumtaz et al (1992) questions the concept of rationality used in these discussion and contends that economic rationality is only an aspect of a larger rationality, which is fundamental to the functioning of these societies.

${ }^{24}$ See Wade (1987) and Ostrom (1990), Van de Laar (1990) for a description of these models.
} 
If we apply the logic of the game [Box 1] to the use of common property resource, and consider the choice facing the two users as being either to cooperate (i.e., follow the rule) or not to cooperate (over-exploit), then the rational strategy of the individual will be not to cooperate. Preference for each individual will have the following order: (1) everyone follows the rule while he shirks (enjoys unrestrained access); (2) everyone, including himself, abides by the rule; (3) no one abides by the rule; (4) he abides by the rule while everyone else shirks.

For the group, most desirable outcome will be the second one - each person observes the rule, but for the individual the most desirable outcome is the first one, i.e. he cheats while everyone else abides by the rule. This will then be the dominant strategy for him (non-cooperation- free riding). By doing so (i.e. cheating) he at least avoids the worst possible outcome for himself - he follows the rule when others enjoy unrestrained access, which results in a Pareto inferior outcome ${ }^{25}$.

- The paradox that individual rational strategies can lead to collectively irrational outcomes challenges the fundamental faith that rational individuals can achieve rational results. According to Campbell the dilemma suggests that It is impossible for rational individuals to cooperate ${ }^{26}$.

Second model of collective action used for critique of CPRs is based on Hardin's Tragedy of the Commons. Hardin's seminal work "The Tragedy of the Commons" has been a cornerstone of debates about common property regimes. Though he presented his case on population problem as one involving no technical solution, his arguments have been widely used by others to condemn communal management of resources.

Hardin envisions a grazing ground which is “open to all”. He then examines the situation from the point of view a "rational" herdsman. Each herdsman has a utility function, where he derives positive utility from selling his animal and negative utility from overgrazing of the pasture. His objective is to maximize his own utility. In this scenario, each herdsman is motivated to add more and more to his herd because he reaps the full, and direct, benefit from his animals but bears only a part of the cost resulting from overgrazing. He then concludes and I quote "each man is locked into a system that compels him to increase his herd without limit - in a world that is limited. Ruin is the destination towards which all men rush, each pursuing his own best interest in a society that believes in the freedom of the

${ }^{25}$ A Pareto optimal outcome occurs when there is no other outcome strictly preferred by at least one player that is at least as good for the other. In this case both prefer cooperate-cooperate outcome so this outcome (confessing) is Pareto inferior.

${ }^{26}$ Cited in Ostrom (1990). 
commons" [Hardin (1968): 1244, emphasis added]. He believes that the only solution to this problem is coercion by an external authority.

Olson's Logic of Collective Action is yet another attempt to theorize the impossibility of rational individuals to pursue collective welfare. Olson questioned the accepted view that individuals with common interest will act together to further those interests, and that possibility of a collective benefit to a group is sufficient to generate collective action. Rather, he suggests and I quote what has come to be the most quoted phrase from his work that "unless the number of individuals is quite small, or unless there is coercion or some other special device to make individuals act in their common interest, rational, self interested individuals will not act to achieve their common or group interests" [Olson (1965): 2]. The argument is that a person who cannot be excluded from the benefits of a collective good once the good is provided will have little incentive to contribute in the provision of that good, unless some kind of coercion is exercised.

Summing up, the common theme running among all three of these models is the free rider problem. The free rider problem results when an individual shirks responsibility to the group. When a person cannot be excluded from the benefits of a joint action he will have a motivation not to contribute in the efforts. If each individual decides to free ride then the action will not take place at all. It points to the impossibility of having a collective action.

This has implication for the management of resources. This school of thought believes that common property management is bound to fail. They base their judgement on the following arguments. (1) each rational individual has a motive to shirk its duty to the group i.e. not contribute in the effort of managing the resource and thereby over exploit it, (2) it is a dominant strategy in the sense that he is always better off choosing this strategy, (3) even if an agreement is struck that requires that each individual will stint on the use of the resource, the strict dominance of the individual strategy makes such co-operation unstable because each individual prefers that the other stints while he overexploits (Runge 1992, p 26).

Under this approach, even if individuals develop a rule to enforce stinting, the problem will not be resolved because no one has an incentive to abide by the rule. Therefore, the enforcement of the rule must come from outside, hence the appropriate property systems are exogenous.

\section{EITHER STATE OR MARKET - THE PUBLIC-PRIVATE DICHOTOMY}

"The alternative of the commons is too horrifying to contemplate. Injustice is preferable to total ruin.” 
(Hardin 1968, p. 1247).

The models discussed above provide a rational for an external agency to take control, some recommend a state control while others opt for a private control. We discuss them one by one.

\section{State Control}

"If ruin is to be avoided people must be responsive to a coercive force outside their individual psyches, a 'Leviathan' to use Hobbes's term”27. Ophuls argues that the tragedy of the commons provides a rationale for state control with major coercive power [cited from Ostrom (1990): 8]. "Common property [read pool] resources require public control if economic efficiency is to result from their development" [Carruthers and Stoner, quoted in Ostrom (1990): 9]. The state control is taken to mean the central government control. The central authority will decide who can use the resource, how and when can he use it. Needless to say that they are assumed to be able governments who possess complete and accurate information about the resource and its use, who are able to device appropriate policies and above that have the ability to implement them, that they have monitoring capabilities, sanctioning reliabilities and zero cost of administration [Ostrom (1990): 8-10]. Breakdown of any of these assumptions means a less than optimal utilization of the resource.

Experience has shown that nationalization of resources has generally resulted in their degradation. Local level resources when appropriated by the central state and then left unmanaged and uncontrolled by the state have deteriorated over time [see Azhar (1993), Commander (1986), Messerschmidt (1986), Arnold and Campbell (1986)]. The de facto management regime is one of non-property, or open access (Bromley 1992, Ostrom 1990). Resource degradation "actually originates in the dissolution of local level institutional arrangement whose very purpose was to give rise to resource use patterns that were sustainable" [Bromley and Cernea (1989): 7].

Further, those advocating a role of state in resource management assume a neutral state. According to the Public Interest theory the political decision makers and the bureaucrats are not neutral in their decisions and they seek to further their self-interests. They are seen as rational utility maximising individuals. So if this concept of economic rationality of an individual was used to advance the notion that communal management is bound to fail, and if it is equally applicable to the decision makers in the state, the

\footnotetext{
${ }^{27}$ Hardin (1978) quoted in Ostrom (1990, p. 9).
} 
implications are very clear - the state management may also fail. The process of deforestation in the South-east Asia (Malaysia, Thailand, Indonesia and Philippines in particular) and the role that large logging concessions have played in that is a case in point.

Blaikie identified factors such as lack of political will, lack of interest on part of the bureaucrats, and incapable administrators, among others, as contributing towards failure of soil conservation programmes [Blaikie (1985): 83-88].

Dasgupta and Mäler (1994) suggest that public ownership need not be a good basis for resource allocation. Decision makers are usually far removed from the site, and have little knowledge of the local ecology, their time horizon are often short, and they are in many instances under the influence of interests groups far removed from the resource. There is little case for centralized control.

\section{Privatization}

Privatization of a resource is basically promoted from the point of view of efficiency. Private ownership internalizes costs and benefits associated with the resource; this creates incentive for the owner to utilize resources more efficiently [Demsetz (1967)]. Under communal ownership there is no incentive to conserve the resource; this is not the case when resources are private property [Tisdell (1993)]. Privatization increases individual responsibility for the environment and rational use of its resources. ${ }^{28}$ Where it is difficult to create private property rights (in the case of mobile resources, e.g.), management must choose from various types of imperfect approximations of property rights [Townsend and Wilson 1987: 318].

Privatization of resources has not served as panacea for their conservation, in fact, in many cases it has contributed to a faster destruction of resources. In India, privatization of land not just had a negative repercussion on the rural poor by their disentitlement from the CPR, but also caused a faster destruction of native vegetation [Jodha 1992, 1994)]. In Brazil, the conversion of forestland to pastures for cattle ranching activities accounted for approximately seventy two percent of land use alterations captured by Landsat imagery up till the late 1980s. Almost 30\% is accounted by a few hundred large-scale, heavily

\footnotetext{
${ }^{28}$ Furoboton and Pejovich (1972), quoted in McCay and Acheson (1987).
} 
subsidized ranches, which was given a boost by the government fiscal incentives to the livestock sector [Browder (1988)] $]^{29}$.

Moreover, it has to be judged if the process is cost effective or not. Privatization of a resource involves parcelling out resources and handing them over to individual owners. There are costs involved in such an action; cost of assigning, defining and enforcing these rights. The fair enforcement of formalized private rights and duties may be prohibitively costly compared with customary arrangements and too high for a village economy to bear [Runge 1992: 20]. Further, privatization has serious distributional implications. The question here is who decides about the assignment of ownership rights. Jodha's research on India indicates that between 49-86 percent of the privatized land ended up under the control of the better segments of the society [Jodha 1986)]. The increased privatization of land marginalizes people and forces them to use the commons more intensively and hence contributes to the shrinking potential of the commons themselves [Blaikie 1985: 130].

\section{RATIONALISING COMMON PROPERTY REGIMES}

Evidence from around the world points out that neither state nor private regimes have been uniformly successful in an effective management of common pool resources. If it can be established that common property regime may be a workable alternative then we do not have to occupy ourselves with the dichotomy of either state or market.

The models of collective action that were used as critique against CPRs have come under severe criticism. Taking the case of prisoner's dilemma, outcomes under this game are based on two key assumptions. (1) players have no communication and they make their choice in ignorance of other's choice, and (2) each player chooses only once and cannot revert his decision afterwards i.e. upon finding what other player has chosen [Wagner (1983)]. Together they imply that two players cannot negotiate among themselves to change the rules of the game and adjust their behaviour accordingly [Wade (1987)]. Any situation that is modelled as the prisoner's dilemma must satisfy these two assumptions. These two assumptions will be used to explain why the common property situation need not be a prisoner's dilemma situation.

While these assumptions are suitable for the game under discussion in which suspects had no previous ties, no code of honour, and no expectation of future interaction, each

29 “SUDAM [Superintendencia do Desenvolvimento da Amazonia] funding of livestock projects has contributed more to deforestation in the Amazon than any other government subsidy program" [Browder 
person knows that he will not have another opportunity to confess; they will be less suitable if the situation is an enduring and recurrent one. If the prisoners know that the game will be played repeatedly the chances that they will cooperate in the hope that others will then do so are much higher [Wade (1987)]. Reality is more complex than this simplified game; here considerations of morality, power and loyalty put checks on free riding. People choose not to free ride when others are cooperating because to do so would run against their moral standards [ibid]. Short-term benefits resulting from shirking may be more than offset by cost arising within the group from breaking the institutional rule. In cases where shirking is not a dominant strategy, cost of reputation loss is very high [Runge (1981)].

Furthering his point in a later publication, Runge (1992) argues that village level decision-making is more akin to the "assurance problem" - where there are no dominant strategies, and decisions are interdependent (expected decisions of others enter one's decision function) - than to a prisoner's dilemma game. In an assurance problem a variety of outcome is possible. What is needed in this situation is a cooperation of a critical mass, and not necessarily every individual, to convince a villager to cooperate and hence benefit from the stinting. It is precisely the role of village level conventions, including common property institutions, to reinforce expectations of collective behavior leading a critical mass of individuals to adopt such a solution [Runge (1992): 27-32].

Hardin's 'Tragedy of the Commons' is also cast in terms of a prisoner's dilemma game, although he himself did not use this parable, but his analysis is based on similar assumptions - no communication and no change in behaviour (Dawes, cited in Wade 1987).

Focussing on Hardin's no communication and no information assumption, it implies that each herdsman is not aware of the action of the others, of the overall condition of the common, and that it is heading toward total 'ruin'. Each herdsman makes a rational decision of adding one more to his herd just before the time of resource breakdown, and hence hastens the destruction. This implication brings out the issue of information people have about the larger system and environment in which they operate [Kimber (1983) cited in Wade (1987)]. While Hardin's parable may hold for very large resource systems (open sea fishing), it is less likely to be a situation of a common property held by a village where the level of interaction, and flow of information among the residents is high, making the monitoring of the condition of commons an easier task. Kimber further point out that Hardin does not distinguish between the situations where resource is vital for the survival of users and where it is not. In situations where it is vital, a rational user will stop at some point well before complete plunder of the resource.

(p, 265]. 
Criticism on Hardin's allegory is replete with one more, and probably the most important, point- his failure to distinguish an open access regime from a common property regime. While his story could easily fit a situation of open access, it is less befitting for a common property regime where a group ownership exists and access is open only to the members of the group. Monitoring the activities of the group and ensuring compliance with the rule stands greater chance under these conditions [Wade (1987)]. When CPRs are wrongly identified as open access regimes, chances for human co-operation and collective action are dismissed [Bromley and Cernea (1989)].

In Olson's logic of collective action, he is true in identifying the tendency of human being to free ride in the absence of coercion, but as discussed earlier that village life has an element of social coercion. Supporters of common property regime claim that this social coercion is very important in reducing possibility of free riding.

As opposed to widely held conception, common property regimes are not free for all. They are structured ownership arrangements in which management rules are developed, group size is known and enforced, incentives exist for co-owners to the rules and sanctions are at work to ensure compliance [Bromley and Cernea (1989)]. Communities have relied on this particular form of property institution to manage resources with reasonable degree of success over long period of time ${ }^{30}$. It is true that success with this kind of property institution has not been an across the board phenomenon, but neither has it been the other way round. The causes of its success are many so are the reasons for its failure ${ }^{31}$.

At times it surfaces as the only rational arrangement under certain circumstances. Runge (1992) discusses why common property regime may be the best possible choice for village conditions, on grounds of both efficiency and equity. He argues that the village life in the developing world has characteristics that make common resource management as the only viable strategy. One such characteristic is relative poverty. This makes the transaction cost of well-defined system of property rights much higher than that under traditional system and too great for them to bear. The more things for which rights are defined the greater the social investment in assignment, definition, and adjudication will be.

Dependence on natural resources is another characteristic. Villagers rely on natural

\footnotetext{
${ }^{30}$ For successful cases of common property regime see Arnold and Campbell (1986), Bromley and Cernea (1989), Bromley (1992), Berkes (ed.) (1989), McCay and Acheson (1987), Mumtaz and Durr-eNayab (1991), and Ostrom and Gardner (1993), Wade (1992).

${ }^{31}$ See Ostrom (1990) for commonalities among successful common property regimes, especially pp. 88-102.
} 
resources for most part of their livelihood and given these resources vary considerably in terms of their productivity over time and space a joint ownership is preferred with a view to avoid unequal distribution of resources. A third characteristic is a high degree of uncertainty with respect to income. This element of uncertainty about future emphasizes inclusion of other as a guard against risks. The expectation is that when one is in need help will come from others. All this creates a structure of incentives that makes collective management a rational strategy. The incentives leading to a particular institutional choice must result from the physical and social environment in which this choice is made.

\section{CONCLUDING COMMENTS}

Some observations are made as concluding remarks. Resource management without proper institutions is doubtful. "Institutions provide a set of constraints which governs the behavioral relations among individuals or group” [Nabli and Nugent (1989): 1335]. Rawls define institutions as public system of rules that specify certain forms of action as permissible, others as forbidden, and provide for certain penalties and defences when violations occur. [C.f. Runge (1984): 807]. "Institution channel the behavior of people with respect to each other and their belongings, providing assurances by setting the 'rules of the game'. They increase the value of a stream of benefits associated with economic activity by coordinating behavior and reducing uncertainty in the realm of human interaction” [ibid. $\mathrm{p}$ 807].

Accordingly, property institutions are public system of rule specifying permissible and forbidden actions in relation to ownership use rights, responsibilities and obligations of individuals and groups (Bromley, cited in Runge 1984, p 807). The choice of institution should be based on the existing socio-economic and political set up. Institutions of public or private property, which have taken roots in the West, may not be replicable, or even applicable particularly for villages in developing countries. Both private regime and state regime are expensive to make effective. Already overstretched states in the developing countries may not be able to provide the necessary resources to make the work in the myriad of microenvironments. A malfunctioning approximation to a formalized system of state control or private system may prove to be inferior form of management when seen in contrast to a local management of resources [Wade (1987)].

Critics of common property regime question the rationality and viability of such a regime, contending that these institutional arrangements do not allow a sustainable management of resources. They then suggest replacing these with either state or market 
solution. The problem with their analysis is that they tend to ignore institutional problems associated with either of the situations. They assume an institution free environment for their analysis, but "neither state nor market is unproblematic in composition, dynamics or effect" [Sinha and Herring (1993: 1431)]. Institutional rigidities are very important in explaining the failures of these management regimes. Bromley (1989) writes, "If the right conditions exist divisibility, mobility, full ownership of all valuable resources, full information, and wellfunctioning markets - then the allocation of all factors of production will be efficient. As a definition this is fine; as a policy prescription in a world where not all valuable resources are fully divisible and capable of individual ownership, where all resources are not fully mobile, where information is imperfect, where many markets are not present, where the future is unrepresented, then our standard advice [of privatization] is suspect” [Bromley (1989): 875].

Common property regime may be the only viable choice under certain (village life) conditions such as: relative poverty, resource dependence, uncertainty, high cost of transaction for alternative institutions. Free riding, which lies at the core of the attack against common property regime, need not be a universal phenomenon. In fact, in the villages of the developing countries social pressure is enough to keep people from free riding. Further, given a high level of interaction, monitoring is not an enormously difficult task in these villages $^{32}$.

All this is not meant to say that common property regime are the panacea for commons. Common property regime can and do break down under internal or external pressures. Population pressures, diversification of the village economy, breaking of cultural ties can put common property regime to a test situation, and it may not come out as triumphant. Similarly, the overall environment in which a common property regime has to survive is crucial in determining the chances of its success. The infusion of modern techniques, government policies, and its attitude in terms of giving priority to common property regime are vital. In most instances common property regimes are not looked at with same degree of importance as private regime and as such do not enjoy an equal level of government support. Privatization of commons, which is offered as a solution to the 'tragedy of commons' cannot work unless enforced (and supported) by state institutions $^{33}$. If CPRs are extended the same level of support from the government agencies, these regimes have a fair chance of success. Common Property Regimes are not inherently inferior types of regimes. In fact, these can be a superior form of regimes under conditions where both state and private property regimes are costly to establish.

\footnotetext{
${ }^{32}$ See Wade (1987) for this point.
} 
Further, since both public and private management of natural resources have not had universal success, it is time to think out of the usual 'either public or private' dichotomy. Combining elements of both public and communal management - collective management - in a pragmatic way is necessary. Experience with forest management in Pakistan has shown that local people can complement government institutions remarkably well in halting forest degradation ${ }^{34}$.

Collective management has been used to identify a great variety of institutional set up including different combinations on the scale from self-management to state management [Sagdahl (1992), c.f. Benjaminsen (1995); 11-12]. ${ }^{35}$ However, it is usually taken to mean shared responsibility of management among different parties ${ }^{36}$. Ideally, the nature of the responsibility is decided according to the comparative advantage of the party. However, experience has shown that the sustainability of such a collective management system requires, as a prerequisite, the presence of local level institutions ${ }^{37}$.

Finally, as Runge (1992) points out different institutions are responses to different local environments, they are likely to range along a continuum of property rights, from pure private rights to pure public rights, depending upon the resource management problem. Search for appropriate institutional arrangement must respect traditions and constraints of local needs. There are no universal recipes for efficient and equitable resource management.

${ }^{33}$ Bromley and Cernea (1989) write, "Private property would be nothing without the requisite authority system that makes certain the rights and duties are adhered to" [Bromley and Cernea (1989): 17].

${ }^{34}$ One of the success stories relates to the case of Chaprote forest, which is situated in the Nagar Valley of the Gilgit district in the Northern Areas of Pakistan, where a village committee, in recognition of their traditional rights, was first merely involved in the management of forest and later on given complete charge of the forest. Mumtaz and Nayab (1992) report the committee was successful in putting a check on the deforestation process [Mumtaz and Nayab (1992)]. The second experience comes from the Kalam Integrated Development Project (KIDP). The KIDP improvised the concept of petty (local) contractors, as against big contractors who were notorious for their alleged collusion with the forest department and overcutting, and also supported involvement of the village community in the making of working plan [Khan and Zurflueh (1994)]. Also See Poffenberger (1995) for a successful experience with forest protection committees, formed of local tribal population, in the Jungle Mahals of West Bengal. He writes that the emergence of these committees is grounded in tribal resistance movements against state control.

${ }^{35}$ Other term used to denote this practice is co management. McCay and Acheson (1987) write that it signifies the political claim of local communities to the right to share management power and responsibility with the state. "It is an attempt to formalize a de facto situation to mutual dependence and interaction in resource management (McCay and Acheson 1987, pp. 31-32).

${ }^{36}$ Seabright (1993) writes that "all forms of collective management involve some asymmetry in the degree of involvement of different parties. At one end of the spectrum is the practice of delegating managerial responsibility to an agent charged with managing the asset on behalf of others; at the other, full participatory decision making” (Seabright 1993, p. 130).

${ }^{37}$ See Mumtaz and Nayab (1992), Khan and Zarflueh (1994) for case studies validating this point. 


\section{REFERENCES}

Arnold, J. E. M., and Campbell, J. G. (1986) Collective management of hill forests in Nepal: The community forestry development project, in Proceedings of the conference on Common Property Resource Management (April 21-26, 1985), Washington D. C.: National Academy Press.

Azhar, R. A. (1993) Commons, regulations, and rent seeking behaviour: The dilemma of Pakistan's guzara forests. Economic Development and Cultural Change, 42(19): 115-129.

Benjaminsen, T. A. (1995) Natural Resource Management and Decentralisation. Towards Comanagement in Mali. Working Paper 1995/3, Centre for Development and the Environment (SUM): University of Oslo.

Berkes, F. (ed.) (1989) Common Property Resources: Ecology and Community-Based Sustainable Development. Belhaven Press, London

Bromley, D. W. (ed.) (1992) Making the Commons Work: Theory, Practice, and Policy, San Francisco: Institute for Contemporary Studies Press.

Bromley, D. W., and Cernea, M. M. (1989) The management of Common Property Resources: Some Conceptual and Operational Fallacies. World Bank Discussion Papers, No 57, Washington D. C.: The World Bank.

Bromley, D. W. (1989) Property Relations and Economic Development: The Other Land Reform. World Development, 17(6): 867-877.

Bromley, D. W., and Chapagain, D. P. (1984) The village against the center: resource depletion in South Asia. American Journal of Agricultural Economics, 66: 868873.

Browder, J. (1988) Public Policy and the Deforestation in the Brazilian Amazon, in R. Repetto and M. Gillis (eds.) Public Policies and the Misuse of Forest Resources. Cambridge University Press, Cambridge.

Commander, S. (1986) Managing India's Forests: A Case Study for the Reforms of Property Rights. Development Policy Review, 4(4): 325-344.

Dani, A. A., C. J. N. Gibbs, and D. Bromley (1987) Institutional Development for Local Management of Rural Resources. Working Report No 2, Honolulu, Hawaii: EastWest Center.

Dasgupta, P., and K. G. Mäler (1994) The environment: The environment and emerging development issues, in: R. Layard, and S. Glaister, (eds.), Cost-Benefit Analysis, Cambridge: Cambridge University Press. 
Demsetz, H. (1967) Towards a theory of property rights. American Economic Review, 57: 347-359.

Dove, M. (1994) Jungle in Nature and Culture, in R. Guha (ed.) Social Ecology. Delhi: Oxford University Press. 90-111.

Dragun, A. K. (1987) Property Rights in economic Theory. Journal of Economic Issues, 21(2): June, 859-868.

Furuboton, E. H., and S. Pejovich (1972) Property rights and economic theory: A survey of recent literature. Journal of Economic Literature, 10: 1137-1162.

Hardin, G. (1968) The tragedy of the commons, Science, 162: 1234-1248.

Hasan, L. (2001) Analysing Institutional Set-up of Forest Management in Pakistan. Research Report 182. Pakistan Institute of Development Economics. Islamabad.

Jodha, N. S. (1992) Common Property Resources; A Missing Dimension of Development Strategies. World Bank Discussion Paper, No 169, Washington D. C.: The World Bank.

Jodha, N. S. (1994) Common Property Resources and the Rural Poor, in R. Guha (ed.) Social Ecology. Oxford in India Readings in Sociology and Social Anthropology. Oxford University Press. Delhi.

Khan, J., and R. Zurflueh. (1994) The Timber Harvesting Ban and Its Implications. Kalam Integrated Development Project, Kalam, Pakistan.

Knudsen, A. J. (1995) Living with the commons: Local institutions for natural resource management. CMI Report R 1995:2. Bergen: Chr. Michelsen Institute

McCay, B. J., and J. M. Acheson (eds.) (1987) The Question of the Commons: The Culture and Ecology of Communal Resources. Tucson, Arizona: The University of Arizona Press.

Messerschmidt, D. A. (1986) People and resources in Nepal: Customary resources management systems in upper Kali Gandaki, in Proceedings of the conference on Common Property Resource Management (April 21-26, 1985), Washington D. C.: National Academy Press.

Mumtaz, S., and D. Nayab (1992) The rationale of common property in the development context. The Pakistan Development Review, 31(3): 259-285.

Mumtaz, S., and D. Nayab (1991) Management arrangements of the Chaprote forest and their implications for sustainable development. The Pakistan Development Review, 30(4): 1075-1086.

Nabli, M. K., and J. B. Nugent (1989) The new institutional economics and its applicability to development. World Development, 17(9): 1333-1347. 
Ostrom, E., and R. Gardner (1993) Coping with asymmetries in the commons: Selfgoverning irrigation systems can work. Journal of Economic Perspectives, 7(4):93-112.

Ostrom, E. (1999) Private and Common Property Rights, in B. Bouckaert and G. D. Geest (eds.) Encyclopedia of Law and Economics. Available at http://encyclo.findlaw.com/2000book.pdf

Ostrom, E. (1990) Governing the Commons: Evolution of Institutions for Collective Action. Cambridge: Cambridge University Press.

Pejovich, S. (1990) The Economics of Property Rights: Towards a Theory of Comparative Systems. Dordrecht: Kluwer Academic Publishers.

Poffenberger, M. (1995) The Resurgence of Community Forest Management in the Jungle Mahals of West Bengal, in D. Arnold and R. Guha (eds.) Nature, Culture, Imperialism- Essays on the Environmental History of South Asia. Delhi: Oxford University Press.

Quiggin, J. (1988) Private and Common Property Rights in the Economics of the Environment. Journal of Economic Issues, 22(4): December, 1071-1087.

Reeve, A. (1986) Property. London and Hampshire: Macmillan.

Runge, C. F. (1981) Common property externalities: Isolation, assurance, and resource depletion in a traditional grazing context. American Journal of Agricultural Economics, (November) 63: 595-606.

Runge, C. F. (1984) Strategic independence in the model of property rights. American Journal of Agricultural Economics, 66: 807-813.

Runge, C. F. (1992) Common property and collective action in economic development, in D. Bromley (ed.), Making the Commons Work. San Francisco: ICS Press.

Seabright, P. (1993) Managing Local Commons: Theoretical Issues in Incentive Design., Journal of Economic Perspectives, 7(4): 113-134.

Sinha, S. and R. Herring (1993) Common Property, Collective Action and Ecology. Economic and Political Weekly, July 3-10; 1425-1432.

Tietenberg, T. (1992) Environmental and Natural Resource Economics. New York: Harper Collins.

Tietenberg, T. (1994) Environmental Economics and Policy. New York: Harper Collins College.

Tisdell, C. (1993) Environmental Economics: Policies for Environmental Management and Sustainable development. 
Townsend, R., and J. A Wilson (1987) An economic view of the tragedy of the commons, in B. J. McCay, and J. M. Acheson, (eds.) (1987) The Question of the Commons: The Culture and Ecology of Communal Resources. Tucson, Arizona: The University of Arizona Press.

Van de Laar, Aart (1990) A Framework for the Analysis of Common Pool Resources. Working Paper 77. Institute of Social Studies. The Hague.

Wade, R. (1992) Common property resource management in South Indian Villages, in D. Bromley (ed.), Making the Commons Work. San Francisco: ICS Press.

Wade, R. (1987) The management of common property resources: collective action as an alternative to privatization or state regulation. Cambridge Journal of Economics, 11(2): 96-106.

Waldron, J. (1988) The Right to Private Property. Oxford: Clarendon Press.

Williamson, O. E. (1985) The Economic Institutions of Capitalism. Free Press, New York. 